\title{
Schumpeterian Churn Dynamics And Regional Productivity Performance
}

Yeonwoo Lee, (E-mail: leeyw@utdallas.edu), University of Texas at Dallas

Donald A. Hicks, (E-mail: dahicks@utdallas.edu),University of Texas at Dallas

\begin{abstract}
This study tests empirically the Schumpeterian premise that the incessant turbulence of an economy in motion, apart from a production function comprised of static inputs, is capable of explaining patterns of economic growth and change. Localized employment "churn" registered as job creation/destruction dynamics is used to account for variations in U.S. metro-regional economic productivity performances during the 1986-99 period. The empirical results suggest that employment turnover and replacement dynamics have large and significant positive effects on localized productivity growth independent of a variety of industrial restructuring processes occurring simultaneously. While employment churn effects are robust across U.S. Census regions, they do not exert a uniform influence on metro-regional productivity performances across time. Until 1996, job creation and destruction dynamics often canceled each other out as metro-regions underwent continued industrial restructuring. Since 1996, however, the positive effects on metro-region productivity growth have been consistently strong. In addition to a strong positive effect on productivity of the emergence of a localized IT sector, both an expanding service sector share of regional employment and a rising public spending share of regional output exert powerful downward pressure on productivity growth rates.
\end{abstract}

\section{Introduction}

¿

n conventional formulations focused on production processes, localized economic growth is viewed primarily as a function of scale economies reflected in urban population size and its correlates. From this perspective, production costs can be expected to decline as firms take advantage of specialized labor and capital pools (Mills, 1967). However, new emergent realities challenge this view. As cascading product and process innovations have loomed in importance and more economic activity than ever before is devoted to creating technical advances, it is increasingly unrealistic to assume that physical size/scale is sufficient to account for variations in urban-regional economic performances (Richardson, 1972; Nakamura, 2000). Moreover, in what Berry (1997) has called "friction-free capitalism," production is no longer so constrained by transportation and transaction costs, and therefore concentration of production no longer implies concentration of work. And, finally, while costminimization has traditionally motivated the quest for productivity gains, today this strategy is increasingly irrelevant - and may even be counterproductive - in emerging competitive contexts in which the revenue prospects flowing from a first-to-market price premium may more than compensate for heavy cost overruns (Hicks, 2001; Gupta and Wilemon, 1990).

The research reported here shifts the focus from an urban region viewed narrowly as a production platform to one which emphasizes localized capacities to host broader and deeper Schumpeterian innovation dynamics in the form of enterprise and employment creation and destruction. As new products, process and production technologies, and organizational forms emerge and new markets are created, underlying dynamics disturb previous equilibrium states and stimulate the emergence of new more competitive ones (Schumpeter, 1934: 66). Moreover, open societies with substantial labor mobility across industries exhibit a greater spread of ideas and growth (Glaeser et al.,

Readers with comments or questions are encouraged to contact the authors via email. 
1992), and simultaneous high rates of job creation and destruction in narrowly defined sectors lend plausibility to the view of an economy subject to ongoing creative destruction (Caballero and Hammour, 1996). Because these dynamics incessantly shift resources from uncompetitive producers to emerging and/or expanding ones, inevitably they have implications for macro-scale output, employment, and productivity outcomes.

Concern over global competitiveness, industrial restructuring and the slow productivity growth across much of the past quarter-century led to a surge of scholarship attempting to interrelate these factors (Baily et al., 1992, 1994; Olley and Pakes, 1992; Baldwin, 1995; Griliches and Regev, 1995; and Roberts and Tybout, 1996). Similarly, others (Campbell, 1998; Cooper et al., 1997) have emphasized technological and skill changes capable of destroying the economic validity of certain industries, firm and jobs and induce the creation of new ones. Together such studies have suggested that restructuring processes make potentially important contributions to an understanding of economic performance. However, because the bulk of this work has been limited to manufacturing industry and firm-level change, less attention has been devoted to linking Schumpeterian churn dynamics to broader macrolevel regional outcomes.

Using industry-specific data for U.S. metropolitan area (MSA and PMSA) economies, this study explores this linkage. It moves beyond the conventional goal of assessing the explanatory power of the static properties of a metro-region's asset base - principally its population size (scale) - to examine empirically the contribution of Schumpeterian dynamics to regional economic performance. By combining independent gross measures of annual job entry and exit for each metro-region to measure the depth of employment churn, we are able to estimate the portion of a region's employment base "in play" in a given year. Viewed over time, this indicator conveys a sense of the velocity of Schumpeterian turnover and replacement dynamics. Then, in the context of a series of multivariate models using several theory-relevant covariates including conventional indicators of static regional assets (population size), we seek to account for variation in labor productivity across U.S. metro-regions.

In the next section we specify the main model used to explore the relationship between employment churn dynamics and localized economic performance. Data development strategies, design and analysis methodology are discussed, along with a variety of issues related to the analysis of pooled time-series and cross sectional data. Our empirical results are reported and interpreted in a final section along with conclusions and implications for future research.

\section{The Basic Model and Hypothesized Relationships}

We have chosen labor productivity growth as our indicator of metro-regional economic performance. By reflecting the competitiveness of individual firms and industries in broader markets, productivity growth influences the prospects for rising living standards, income and general economic opportunities for workers, thus making it one of the most important yardsticks of aggregate economic performance. In order to analyze the combined and separate effects of employment creation and destruction on localized productivity growth, this study adopts a Constant Elasticity of Substitution (CES) production function approach, of which a Cobb-Douglas function is a special case (Arrow et al., 1961). It is assumed that the metropolitan-scale (P/MSA) economies are distinct and open, sharing common pools of capital and labor (Lobo and Rantisi 1999). Aggregate metro-scale output is determined using a twofactor production function that shows the relationship between inputs and outputs and a productivity efficiency factor.

$$
\mathrm{Q}_{j t}=\mathrm{A}_{\mathrm{jt}} \mathrm{F}\left(\mathrm{K}_{\mathrm{j} \mathrm{t}}, \mathrm{L}_{\mathrm{j}}\right)
$$

where $Q$ is real output; $K$ is the metro-scale capital stock; $L$ is its labor or employment; $t$ and $j$ are time and metro region, respectively. And $A$ is an efficiency parameter which changes output proportionately for given quantities of input. For the purpose of this study, the relationship between dependent variable and explanatory variables is hypothesized as following with all variables expressed in natural logarithm form: 


$$
\begin{aligned}
\ln Q L_{i t} & =\beta_{0}+\beta_{1} \ln R E A L_{i t}+\beta_{2} \ln I T S H_{i t}+\beta_{3} \ln M S H_{i t}+\beta_{4} \ln S S H_{i t}+\beta_{5} \ln S G o v_{i t}+\beta_{6} \ln \text { Pop }_{i t} \\
& +\beta_{7} \ln H C_{i t}+\beta_{8} \ln \text { Rwage }_{i t}+\beta_{9} Y 9699_{i t}+\varepsilon
\end{aligned}
$$

where, $Q L$ is output-per-worker; $R E A L$ is rate of job reallocation; ITSH is IT sector share of regional Gross Domestic Product (GDP); $M S H$ is the manufacturing sector share of regional GDP; SSH is the service sector share of regional GDP; SGov is the public sector share of regional GDP; POP is population size; $H C$ is human capital; Rwage is real wage; $Y 9699$ is dummy variable which takes the value of 1 for years 1996-99 and 0 otherwise; $\varepsilon$ is error term; and $\beta_{i}$ are coefficients for metro region $(i)$ and time $(t)$, respectively.

Dependent Variable: Labor productivity is typically measured by computing the ratio of the real-dollar value of total output to the number of employees or employee hours-worked. However, because direct measures of metro-scale productivity performances are unavailable, we developed what amounts to a "shadow" measure of Gross Regional Product (GRP) following Hicks and Nivin (2000:120). This approach proceeds on the assumption of relative uniformity of industry-specific labor quality across metro-regions. We regard this assumption as reasonable, because as goods producers and service providers are increasingly disciplined by competition in nation-scale and even global markets, the likely effect is to narrow intra-industry labor productivity differentials across regions.

Main Explanatory Variable -Job Reallocation: As micro-level research on firm-level entry and exit, expansion and contraction suggests, as older, inefficient and unproductive capital is destroyed, new, efficient and productive capital is created. This implies that productivity variability is likely linked closely to job reallocation, as workers matched with unproductive capital lose their jobs and new more productive labor-capital matches are made. However, to date direct evidence of the relationship between reallocation and productivity has been limited to intrafirm or intra-industry settings. In this study we extend this logic to metro-scale regional economies by capturing the cumulative effects of within- and between-industry productivity-enhancing employment reallocation processes.

Following Davis, Haltiwanger and Schuh's (1998) approach to measuring of job "reallocation," we develop a similar measure using raw employment data for 73 two-digit SIC industries covering virtually the entire economy for each U.S. metro-region across the 1986-99 study period. Individual industries are categorized by whether they have added jobs or lost jobs from each quarter to the same quarter one year earlier, so as to adjust for seasonality trends. Positive job changes are summed across all industries for a given year, and the cumulative total volume is used as an estimate of "job creation" for a given period. Similarly, the sum of job losses between a given quarter and the same quarter a year earlier across all contracting industries constitutes total "job destruction" for a given year. Then, each is expressed as a rate by dividing the sum of the gross job changes for four quarters of a given year by the end-of-period tally of total jobs. ${ }^{1}$ Then, the measure of job reallocation $(R E A L)$ is constructed by summing both the absolute value of job creation and job destruction.

Industrial Restructuring Dynamics: The process of regional economic transformation and restructuring involves shifting industrial structures as new industries emerge and existing industries are transformed (Florida, 1996). Noyelle and Stanback (1983) have provided a clear description of the industrial-sectoral restructuring that reshaping the U.S. economy during the post-World War II period. Nakamura (2000) also shows how over the $20^{\text {th }}$ century, the U.S. economy has experienced fundamental shifts from goods production to services provision reflected

${ }^{1}$ Alternatively, the procedure can be expressed as follows:

$$
\begin{aligned}
& \text { Job Creation }_{t}=\frac{\sum_{i=1}^{73}\left(e_{i q t}-e_{i q t-1}\right)}{E_{q t-1}} \quad \text { if } e_{i q t}-e_{i q t-1}>0 \\
& \text { Job Destruction }_{t}=\frac{\sum_{i=1}^{73}\left(e_{i q t}-e_{i q t-1}\right)}{E_{q t-1}} \quad \text { if } e_{i q t}-e_{i q t-1}<0
\end{aligned}
$$

where $\left(\mathrm{e}_{q t}-\mathrm{e}_{q t-1}\right)$ is employment change, $i, q$ and $t$ are a given industry, quarter and year, respectively. 
in both employment and output. Structural shifts of this kind occur through processes that create new demand and wealth while destroying older market structures. The model tested below includes controls for a variety of privatesector inter-and intra-industry restructurings involving the emerging information technology (IT), manufacturing, and services sectors, as well as for inter-sectoral shifts between the public and private sectors. Each of these will be discussed separately below.

Intra-Sectoral Shifts: Manufacturing sector productivity growth has exceeded that for all but a few industries in the services sector over the past three decades (Denison, 1973; Kozicki, 1997), and the newly coherent IT industries has recently registered the highest productivity growth rates of all (Pilat, 1998). Because a sector's economic significance and growth are no longer clearly registered as rising employment levels, all sectoral dynamics are measured in terms of outputs rather than employment inputs. Three variables are introduced to capture distinct restructuring processes within the private sector: 1) GDP shares of total earnings accounted for by the IT sector $\left.\left(I T S H_{j t}\right)^{2} ; 2\right)$ manufacturing sector $\left(M S H_{j t}\right)$; and 3) services sector $\left(S S H_{j t}\right)^{3}$, respectively. The effects of each of these three intra-sectoral shifts on metro-scale productivity are expected to differ. While it is difficult to specific in advance the precise direction and intensity these influences, we hypothesized that IT and manufacturing sector shares will each exert a positive influence on productivity growth, while the services sector share will exert a negative influence.

Inter-Sectoral Shifts: Private vs. Public: The influence of inter-sectoral shifts between the public and private sectors on economic performance has long attracted scholarly attention. Debate has swirled persistently around questions of how big government must be before it becomes a drag on the economy. One point of view suggests that government fiscal policies can stimulate economic growth directly through investment of public funds - or indirectly by steering or leveraging private investment - so as to compensate for underinvestment in growth-inducing assets such as fundamental knowledge via basic scientific research and labor skills via formal schooling. Counterarguments hold that increased public spending is likely to be detrimental to economic performance, largely because such spending imposes on the private sector burdensome costs that distort economic incentives.

Empirical research on the effect of government spending as a share of GDP on economic performance has yielded often conflicting results (Landau, 1983; Ram, 1986; Aschauer 1990; Barro, 1990, 1991; Sheehey, 1993; Knoop, 1999). While government consumption share of GDP appears to have a negative effect on productivity growth, selected public infrastructure investments have been found to have a positive influence. Against this backdrop the present study investigates whether rising shares of total localized public spending by all levels of government relative to total local output (SGov) retards or accelerates metro-region productivity growth over time. The expected relationship, size, sign and significance of the coefficient relating public spending from all sources on productivity growth is indeterminate because the measure of total government expenditures contains two consumption components, one often thought to have a negative effect and another have a positive effect on growth.

Economic Scale: Scale economies are a defining feature of conventional urban economics literature. This is seen as far back as Marshall's (1890) frequently cited passages on how cities provide an environment of close contacts and neighborhoods, as well as more recently in empirical work scale effects on urban productivity. In this study, the size of a metro-region's population is used to measure of economic scale. The effect on per-worker output is expected to be positive.

Human-Capital Endowments: External economies arising from human capital investment are thought to be critical to the productivity or economic growth (Romer, 1986; Lucas, 1988). Workers with relatively high educational attainment are often found in firms deploying new process and/or production technologies. Denison (1985) estimated that 20 percent of the growth in output-per-worker over the period of 1929-1982 was associated with the increase in the general educational level. However, when temporal and panel dimensions are taken into account for the role of human capital, an insignificant or negative coefficient can result (see e.g., Pineres and Ferrantino 2000; Islam 1995; De Gregorie, 1992). Therefore, it is possible that there exists a pervasive temporal effect of human capi-

\footnotetext{
${ }^{2}$ U.S. Department of Commerce defines IT industries based on four-digit SIC codes. But because of data availability this study categorizes IT industries using three-digit SIC codes.

${ }^{3}$ The classification of services sector used follows Noyelle and Stanback's (1983).
} 
tal, resulting in a negative coefficient. When young relatively well-educated workers first enter the labor market, they may not contribute to productivity growth as much as the older workers with less formal education but more work experience. However, over time as the well-educated workers gain that experience, this contribution likely grows. In addition, while there may be a positive relationship between human capital and labor productivity growth in a single cross-section or metro region, there may be no such relationship in the panel-structured data. In this study in order to control for human capital endowments, the share of a region's population with a bachelor's degree is introduced as a covariate and is expected to be positively correlated with labor productivity.

Real Wage: The modified CES production function does not include the stock of metropolitan physical capital that is known to be scarce and inadequate, if available at all. Instead, the labor productivity function does contain a Real Wage term. Real wage is computed by dividing average earnings of total non-agricultural workforce by the Consumer Price Index (CPI) for each metro region over time. Because high wages are believed to reflect higher productivity, the real wage is expected to be positively correlated with urban labor productivity.

Secular Economic Change: In late 1990s, the U.S. economy started to experience a strong resurgence in labor productivity. According to Stiroh (2001), after growing only 1.3 percent per year from 1973 to 1995 , labor productivity growth jumped to 2.5 percent from 1996 to 1999 . However, economists and policymakers have not agreed on what was responsible for the resurgence. For example, Gordon (2000) argues that the recent productivity acceleration was due to cyclical forces. Others reach a similar conclusion that a combination of accelerating technical progress in high-tech industries and the investments in so-called "information technology" has played a key role in productivity revival (Jorgenson and Stiroh 2000). In this study, the year 1996 is introduced as structural threshold demarcating the IT investment surge, with 1996 and subsequent years coded "1" and previous years coded "0".

\section{Data Development Issues and Methodology}

Primary data resources used in this study were obtained from RFA Dismal Sciences (West Chester, Pennsylvania), an economic consulting firm which develops and maintains raw data from a wide variety of sources including the Bureau of Labor Statistics (BLS) of the U.S. Department of Labor, the Bureau of Economic Analysis (BEA) and the Bureau of the Census of the U.S. Department of Commerce. The data base developed for this study includes annual data for the years 1986-99, a 14-year time span dictated by the unavailability of data on key covariates prior to 1986. The unit of analysis in this study is the metro-region, and annual data were developed for 187 Metropolitan Statistical Areas (MSAs) and Primary Metropolitan Statistical Areas (PMSAs). The use of pooled cross-sectional/time series data increases the degrees of freedom, improves efficiency of estimation, and is an appropriate method for this kind of research. However, there are several possible problems that arises from concatenating such data.

Stationarity and Cointegration: Time series data exhibit stationarity when means and variances are constant and the series reveals neither long-term trend nor short-term periodic fluctuations. However, it is wellestablished that economic time series data are seldom stationary. Because the regression of non-stationary variables is likely to suffer from spuriousness, we used the Im, Pesaran and Shin (1997) - IPS test statistic as applied to heterogeneous panels. ${ }^{4}$ The results indicated that all variables were not stationary at conventional level. After differencing each time series to achieve stationarity and then applying the unit root tests for the first difference $I(1)$, the results indicated that all time series were now stationary.

Analyzing differenced variables results in short-term relationships, while losing the long-term relationship. However, if non-stationary time series variables are cointegrating, then we can build both a long-run relationship and a short-run dynamic relationship through the use of an error correction process (Engle and Granger, 1987). To perform the cointegration of the labor productivity function, we examined the residuals from the equation (2) esti-

\footnotetext{
${ }^{4}$ The IPS test statistic (Psi[t-bar] statistic) is based on the mean of the individual Dickey-Fuller t-statistics of each unit in the panel and assumes that all series are non-stationary under the null hypothesis. Because most time series are characterized by trends and serial correlations, lag and trend are introduced based on the Akaike Information Criterion (AIC), which has been widely used in the literature for the selection of the optimal lag length.
} 
mated via GLS procedure allowing for group-wise heteroscedasticity and group-specific autocorrelation. Then, we applied the IPS test, including an intercept and a trend. The t-bar statistic supports the existence of cointegration. Because of this support for cointegration $I(0)$, there is a long-term relationship among them. To build a long-run relationship, the error correction mechanism popularized by Engle and Granger (1987) was taken into account in the model.

Endogeneity -Instrumental Variable Estimators: Because labor productivity and wage are jointly dependent variables, a regression will simply yield the conditional expectation of productivity given wage in a CES production function (Dhrymes, 1965). Moreover because the wage differences among metropolitan areas might be generated by the interaction of the relative labor supply and demand schedules, the parameter estimators will be subject to simultaneous equation bias. In that case, the estimates are not only biased, but also inconsistent because the independent variables are a function of the disturbance (Hoch, 1958). As a causality test, we follow the Engle and Granger (1987) two-step procedure, whereby if two variables are integrated of order one and cointegrated, then either uni-directional or bi-directional Granger causality must exist in the $\mathrm{I}(0)$ variables. The test results suggest that the growth of real wage Granger-cause the growth of labor productivity, but the growth of labor productivity does not Granger-cause. Indeed, the F-Statistics indicate bi-directional causality between labor productivity and real wage. To confirm these results, we applied the Durbin-Wu-Hausman (DWH) test to the production function to test for endogeneity. The result indicates that the null hypothesis of exogeneity of real wage is rejected at the conventional level. In order to remedy this problem, we use a two-stage least squares (2SLS) approach with the predicted value of real wage estimated with metropolitan-level instrument variables. ${ }^{5}$ The estimated real wage is a good proxy for real wage $\left(R^{2}=0.92\right)$.

Serial Correlation and Heteroscedasticity: In a pooled time-series and cross-sectional setting, common problems are serial correlation and heteroscedasticity. Thus, the Durbin-Watson d statistic is used to determine whether there is first-order serial correlation in the error term and indicates that there is no first-order autocorrelation at conventional level. The Breusch-Pagan, Cook and Weisberg and White general tests are employed to confirm the presence of heteroscedasticity. In addition, the Wald test for group-wise heteroscedasticity in cross-sectional timeseries FGLS regression model is applied. All test results indicate that there is heteroscedasticity at conventional level. In response, we use Feasible Generalized Least Squares (FGLS) procedure allowing for group-wise heteroscedasticity. ${ }^{6}$

\section{Empirical Results}

The final model is constructed as follows:

$$
\begin{aligned}
\Delta \ln Q L_{i t} & =\beta_{0}+\beta_{1} \Delta \ln R E A L_{i t}+\beta_{2} \Delta \ln P_{o p}+\beta_{3} \Delta \ln H C_{i t}+\beta_{4} \Delta \ln \text { Rwage }_{i t}+\beta_{5} \Delta \ln I T S H_{i t} \\
& +\beta_{6} \Delta \ln M S H_{i t}+\beta_{7} \Delta \ln S S H_{i t}+\beta_{8} \Delta \ln S G o v_{i t}+\beta_{9} Y 9699_{i t}+\beta_{10} E C T_{t-1}+\varepsilon
\end{aligned}
$$

Where $\Delta$ denotes first difference of logs of variables; ECT is an Error Correction Term representing the deviations from the long-run equilibrium relationship at time $t$; and $\varepsilon$ is the error term with the usual properties.

The primary focus of this paper is whether the business churn dynamics (REAL) taking place within (and

\footnotetext{
${ }^{5}$ The instruments are unemployment, population, share percent of age 15-24 population, share percent of 25year-over population with bachelor's degree, IT sector's share of GDP, manufacturing sector's share of GDP, service sector's share of GDP, public sector's share of GDP and metropolitan dummies.

${ }^{6}$ In this study, it is very likely that the macroeconomic factors that affect any metro-regional economies affect them all to varying degrees. Accordingly, it seems reasonable to allow some correlation of the disturbances across metro-regions. For testing the hypotheses that the disturbance terms are independent, the Lagrange Multiplier (LM) test developed by Breusch-Pagan (1980) is applied in the context of FGLS estimation. The result leads to rejection of the hypothesis of independence. A preferable correction might be to use pooled OLS and make the appropriate correction to the asymptotic covariance matrix. But in this situation there remains the possibility of accommodating cross unit heteroskedasticity and therefore, the groupwise heteroscedasticity model is appropriate because the estimates are consistent and more efficient than those derived from OLS, although the standard errors will be inappropriate (Green, 1997).
} 
across) U.S. metro-regions account for variation in metro-regional productivity performance over time. In order to investigate this possibility, the model is tested using Ordinary Least Squares (OLS) and Feasible Generalized Least Squares (FGLS) estimation techniques in order to compare the estimates. Then, fixed-effect models are employed to control for unmeasured metro-specific contributions. Finally, the robustness of models is examined to get a clearer picture of the roles of dynamic processes across time.

\subsection{Regression Results and Interpretation}

Table 1 compares the estimates obtained from both OLS and heteroscedasticity-corrected (FGLS) estimation techniques. The OLS technique is applied both with and without panel-corrected standard errors based on the alternative specification forms for the assumed covariance of the disturbances across the panels. One is to assume that the disturbances are independent across panels and another is specified such that the disturbances are heteroscedastic and contemporaneously correlated across the panels. Each estimation technique - OLS and FGLS - is also applied to models in which only within-metropolitan variations are permitted to vary over time (Fixed), as well as to those in which cross-sectional variations over time are not controlled (Not Fixed). The former model set is assumed to control for unmeasured metro-specific contributions to productivity growth.

The results show that the general model can explain quite well the variation in metro-regional labor productivity growth. Columns 2, 4 and 6 report the results based on whether or not unmeasured metro-region effects are controlled. When the first and second OLS estimates are compared, overall explanatory power increases from 39 percent to 44 percent of the variance in the dependent variable. This suggests that the explanatory power of one or more predictors had been suppressed by factors brought under control by the fixed-effect technique. Comparing OLS estimations with and without panel-corrected standard errors, the only notable differences are in standard errors of the estimated coefficients. Panel-corrected standard error model tends to be associated with slightly higher standard errors, which accounts for why the coefficients on $\Delta \mathrm{L} n \_\mathrm{MSH}, \Delta \mathrm{Ln} \_\mathrm{POP}$, and $\Delta \mathrm{Ln} \_\mathrm{RWAGE}$ fail to achieve statistical significance in the panel-corrected specification without fixed-effects controls.

On the other hand, we can see that significance levels and signs are relatively consistent across OLS and FGLS estimates. However, the standard errors associated with FGLS estimates are typically smaller than those associated with OLS estimates, whether panel-corrected or not. This suggests that the estimates of FGLS are more efficient than those of OLS. Based on the patterned results in Table 1, it appears that the presence of heteroscedasticity in the non panel-corrected model and the remaining possibility of accommodating cross unit heteroskedasticity in the panel-corrected model is of such salience that the econometric analyses in this study will draw primarily on FGLS estimates.

Examining Table 1 more closely, it appears that the influence of job reallocation on metro-regional labor productivity growth is significant both statistically and substantively. The elasticity of job reallocation $\left(\Delta \mathrm{Ln} \_\right.$REAL) is 0.005 , indicating a statistically significant and positive effect. In effect, the deeper and more turbulent the employment churn experienced by a metro-regional economy, the greater the rate of labor productivity change. This expected effect is revealed in specifications both with and without fixed-effect controls.

Table 1 also reveals that various industrial structuring dynamics exert quite different influences on metroregional productivity. The "shift-to-services," which has emerged as a defining feature of the post-WWII advanced economic development, ${ }^{7}$ also appears to influence productivity. The greater the share of a region's output derived from the broad services sector, the lower the rate of productivity growth. However, no such influence is associated with shifting output shares associated with goods production (i.e., manufacturing). These divergent outcomes are unexpected, especially since in the larger economy productivity levels in manufacturing tend to be higher than all but a few advanced services. ${ }^{8}$

\footnotetext{
${ }^{7}$ Most OECD countries such as Finland, Norway, Portugal, Spain, Sweden and the United Kingdom exhibit rises in labor productivity could be attributed to the manufacturing industries and declines in the less-productive services sector (OECD, 1998).

${ }^{8}$ The absence of a significant positive effect associated with short-term shifts in the output contribution attributable to manufacturing is something of a surprise. One possible explanation is that much of the activities taking place in manufacturing are actually highly sophisticated services such as product design and development whose net productivity impact is a counterweight to the steady decline in manufacturing employment.
} 
Table 1. Comparison Estimation Results for Productivity Growth Model

\begin{tabular}{|c|c|c|c|c|c|c|}
\hline \multirow{3}{*}{ Independent Variables } & \multicolumn{4}{|c|}{ OLS } & \multirow{2}{*}{\multicolumn{2}{|c|}{$\begin{array}{c}\text { FGLS } \\
\text { Groupwise } \\
\text { Heteroscedasticity-adjustec }\end{array}$}} \\
\hline & \multicolumn{2}{|c|}{$\begin{array}{l}\text { Not Panel-Corrected } \\
\text { Standard Errors }\end{array}$} & \multicolumn{2}{|c|}{$\begin{array}{c}\text { Panel-Corrected Standard } \\
\text { Errors }{ }^{1)}\end{array}$} & & \\
\hline & Not Fixed & Fixed & Not Fixed & Fixed & Not Fixed & Fixed \\
\hline \multicolumn{7}{|l|}{ Intercept } \\
\hline$\Delta \mathrm{Ln} \_\mathrm{REAL}$ & $\begin{array}{l}.008^{* * *} \\
(.001)\end{array}$ & $\begin{array}{c}.007 \\
(.006)\end{array}$ & $\begin{array}{l}.008^{* * * *} \\
(.002)\end{array}$ & $\begin{array}{c}.007 \\
(.005)\end{array}$ & $\begin{array}{l}.007^{* * *} \\
(.001)\end{array}$ & $\begin{array}{l}.004 \\
(.004)\end{array}$ \\
\hline$\Delta \mathrm{Ln} \_I T S H$ & $\begin{array}{l}.008^{* * * *} \\
(.002)\end{array}$ & $\begin{array}{l}.008^{* * *} \\
(.002)\end{array}$ & $\begin{array}{l}.008^{* *} \\
(.004)\end{array}$ & $\begin{array}{l}.008^{* * *} \\
(.003)\end{array}$ & $\begin{array}{l}.005^{* * * *} \\
(.002)\end{array}$ & $\begin{array}{l}.005^{* * *} \\
(.002)\end{array}$ \\
\hline$\Delta \mathrm{Ln} \_\mathrm{MSH}$ & $\begin{array}{l}.021^{* * *} \\
(.005)\end{array}$ & $\begin{array}{l}.022^{* * * *} \\
(.005)\end{array}$ & $\begin{array}{l}.021^{* * *} \\
(.007)\end{array}$ & $\begin{array}{l}.022^{* * *} \\
(.007)\end{array}$ & $\begin{array}{l}.016^{* * * *} \\
(.005)\end{array}$ & $\begin{array}{l}.019^{* * * *} \\
(.004)\end{array}$ \\
\hline$\Delta \mathrm{Ln} \_\mathrm{SSH}$ & $\begin{array}{l}-.015^{* *} \\
(.007)\end{array}$ & $\begin{array}{l}-.009 \\
(.007)\end{array}$ & $\begin{array}{l}-.015 \\
(.011)\end{array}$ & $\begin{array}{l}-.009 \\
(.011)\end{array}$ & $\begin{array}{l}-.003 \\
(.006)\end{array}$ & $\begin{array}{l}.005 \\
(.006)\end{array}$ \\
\hline$\Delta$ Ln_SGov & $\begin{array}{c}-.504^{* * * *} \\
(.019)\end{array}$ & $\begin{array}{l}-.521^{* * * *} \\
(.019)\end{array}$ & $\begin{array}{c}-.504^{* * *} \\
(.039)\end{array}$ & $\begin{array}{l}-.521^{* * *} \\
(.038)\end{array}$ & $\begin{array}{l}-.428^{* * *} \\
(.019)\end{array}$ & $\begin{array}{l}-.448^{* * *} \\
(.018)\end{array}$ \\
\hline$\Delta \mathrm{Ln} \_\mathrm{POP}$ & $\begin{array}{c}-.074^{* * *} \\
(.006)\end{array}$ & $\begin{array}{c}-.062^{* * * *} \\
(.006)\end{array}$ & $\begin{array}{c}-.074^{* * * *} \\
(.010)\end{array}$ & $\begin{array}{c}-.062^{* * *} \\
(.009)\end{array}$ & $\begin{array}{c}-.060^{* * *} \\
(.005)\end{array}$ & $\begin{array}{c}-.048^{* * * *} \\
(.005)\end{array}$ \\
\hline$\Delta \mathrm{Ln} H \mathrm{HC}$ & $\begin{array}{l}.090^{* *} \\
(.036)\end{array}$ & $\begin{array}{l}.257^{* * * *} \\
(.059)\end{array}$ & $\begin{array}{l}.090 \\
(.056)\end{array}$ & $\begin{array}{l}.257^{* * * *} \\
(.100)\end{array}$ & $\begin{array}{l}.121^{* * * *} \\
(.031)\end{array}$ & $\begin{array}{l}.332^{* * * *} \\
(.048)\end{array}$ \\
\hline$A \mathrm{~L}$ RWAGE & $\begin{array}{l}-.002 \\
(.001)\end{array}$ & $\begin{array}{l}-.001 \\
(.001)\end{array}$ & $\begin{array}{l}-.002 \\
(.002)\end{array}$ & $\begin{array}{l}-.001 \\
(.002)\end{array}$ & $\begin{array}{l}-.002 \\
(.001)\end{array}$ & $\begin{array}{l}-.001 \\
(.001)\end{array}$ \\
\hline Y96 99 & $\begin{array}{l}.054^{* * * *} \\
(.013)\end{array}$ & $\begin{array}{l}.035^{* * *} \\
(.013)\end{array}$ & $\begin{array}{c}.054 \\
(.050)\end{array}$ & $\begin{array}{l}.035 \\
(.050)\end{array}$ & $\begin{array}{l}.066^{* * * *} \\
(.011)\end{array}$ & $\begin{array}{l}.050^{* * * *} \\
(.010)\end{array}$ \\
\hline ECT & $\begin{array}{l}.007^{* * * *} \\
(.001)\end{array}$ & $\begin{array}{l}.011^{* * * *} \\
(.001)\end{array}$ & $\begin{array}{l}.007^{*} \\
(.004)\end{array}$ & $\begin{array}{l}.011^{* * *} \\
(.004)\end{array}$ & $\begin{array}{l}.008^{* * * *} \\
(.001)\end{array}$ & $\begin{array}{l}.012^{* * * *} \\
(.001)\end{array}$ \\
\hline & $\begin{array}{l}-.005 \\
(.004)\end{array}$ & $\begin{array}{c}-.083^{\text {***** }} \\
(.011)\end{array}$ & $\begin{array}{l}-.005 \\
(.009)\end{array}$ & $\begin{array}{l}-.083^{* *} \\
(.037)\end{array}$ & $\begin{array}{c}-.007^{* *} \\
(.003)\end{array}$ & $\begin{array}{c}-.100^{* * *} \\
(.010)\end{array}$ \\
\hline $\begin{array}{l}\text { Adjusted } \mathrm{R}^{2} \\
\text { Log Likelihood } \\
\text { F or Wald Chi-2 } \\
\text { Test statistics }\end{array}$ & $\begin{array}{c}0.39 \\
157^{* * *} \\
\text { BP }^{* * *} \\
\text { White }^{* * *}\end{array}$ & $\begin{array}{c}0.44 \\
11^{* * * *} \\
\mathrm{BP}^{* * * *} \\
\mathrm{CW}^{* * *}\end{array}$ & $\begin{array}{c}0.39 \\
463^{* * *}\end{array}$ & $\begin{array}{l}0.49 \\
566^{* * *}\end{array}$ & $\begin{array}{c}6262 \\
1385^{* * *}\end{array}$ & $\begin{array}{c}6478 \\
2165^{* * *}\end{array}$ \\
\hline
\end{tabular}

Notes: ${ }^{1)}$ Standard errors are corrected under assumption that the disturbances are heteroskedastic and contemporaneously correlated across the panels; *** Significant at $0.01 ; * *$ Significant at 0.05 ; *Significant at 0.10 .

It is also possible that by the mid-1980s and the beginning of the period under study, the bulk of the industrial restructuring associated with manufacturing's transformed role in an advanced economy was already behind us. 
The effect of the emergent IT sector on localized productivity performances is revealed in two distinct ways. First, there is a statistically significant positive effect associated with the long-term emergence of the IT sector over the entire study period. This effect is all the more notable because it coexists with a strong independent effect associated with cyclical forces (Gordon, 2000) that generated an IT investment surge captured by the Y96_99 predictor. ${ }^{9}$ In other words, even after accounting for the sudden acceleration of IT investment after 1996, the more secular IT-oriented restructuring process appears to have registered a powerful positive influence on localized productivity growth.

Table 1 also reports a significant negative impact of local government spending on private sector economic performance. The coefficient on $\Delta \mathrm{Ln} \_\mathrm{SGov}$ indicates that increases in localized public sector spending as a share of a region's total output are associated with lower rates of productivity growth. This result is consistent with the view that the public sector can impose a significant burden on the private sector economic performances in U.S. metro regions.

As expected, agglomeration economies as measured by population growth also wield a positive and significant independent influence on productivity. Glaeser and Shapiro (2001) have explained this century-long importance of agglomeration as a demand for super-high density either in production of high-idea commodities or in their consumption. A striking pattern across specifications is that the coefficients on population growth are nearly three times larger in the fixed-effects models than they are in models in which these metro-regional attributes are left uncontrolled. This suggests that the older more conventional perspective on economic performance which has assigned a primary role to relatively static attributes of an economy such as population size and the returns to economic scale associated with this attribute, has not so much been supplanted as supplemented by the revealed importance of the employment churn dynamics roiling beneath the surface of a region's economy.

Somewhat surprisingly, there is no evidence suggesting that human capital measured in terms of the population share with at least a bachelor's degree influences a metro-region's productivity performance. This result contradicts results reported by others (e.g., Romer, 1986; Rauch, 1993; Simon, 1998; Glaeser and Shapiro, 2001) who have argued that human capital exerts a powerful positive influence on economic performance. However, the results reported here are consistent with those reported by Pineres and Ferrantino (2000) and Islam (1995).

As expected, real wage growth is associated with productivity growth. However, it is also possible that rising real wages are a consequence, rather than a cause, of rising productivity in metro-regions. The direction of this relationship merits further scrutiny. Finally, the fixed-effect coefficient on the Error Correction Term (ECT) suggests that the labor productivity in the U.S. metro-economies was adjusting very quickly to its long-run path at a rate of an estimated 10.0 percent per year, compared to the far slower rate $(0.7$ percent $)$ in the model in which unmeasured metro-specific effects remained uncontrolled.

Table 2 reports results of analyses that decouple these two underlying employment dynamics. We can see that relatively rapid job creation appears to have had a depressant effect on productivity growth throughout the Northeast, while significantly accelerating productivity growth in the Midwest. Job creation appears to have had no effect in either the South or West. Meanwhile, the job destruction dynamic appears to have wielded a powerful positive influence on productivity growth in all Census regions except the Northeast. Overall, this suggests that for most U.S. metro-regions productivity growth is influenced more by the capacity to shed jobs from relatively lowproductivity enterprises and industries than by its capacity to create jobs in high-productivity enterprises and industries. However, the salutary job-shedding route to productivity growth does not appear to have been open in the Northeast. Throughout this Census region, by contrast, an alternative process may be indicated. That relatively rapid job creation appears to have actually depressed productivity growth throughout the Northeast suggests that the jobs being created tended to be in low-productivity enterprises and industries thereby suppressing overall productivity growth. As Norton (1986) suggested, deindustrialization primarily reflected the "destructive" side of creative destruction in mature metro-regions of Northeast in particular. The region's productivity prospects would be influenced as people who lost their jobs due to plant shut-downs, contractions, and out-migrations filtered into new jobs

\footnotetext{
${ }^{9}$ Inclusion of this term has the effect of employing an interrupted times series design to detect an IT investment effect.
} 
with lower pay and less well-developed benefit packages, thus making below-average contributions to the overall output of the region. So, while such job destruction functioned as a positive driver for productivity growth elsewhere, it was not associated with such beneficial effects throughout the Northeast. Meanwhile, as Florida (1996) suggested, strong positive effects of both job creation and destruction throughout the Midwest may indicate that the process of economic transformation has been sufficiently powerful that it could register in older regions. These findings should stimulate significant re-appreciation of the salutary role of departing jobs and dying industries in the larger industrial transformations taking place throughout the U.S. economy.

Table 2. Independent Job Creation and Destruction Effects on Productivity Growth

\begin{tabular}{|c|c|c|c|c|c|}
\hline Independent Variables & All & Northeast & Midwest & South & West \\
\hline Intercept & $\begin{array}{l}.007^{* * * *} \\
(.001)\end{array}$ & $\begin{array}{l}.011^{* * * *} \\
(.001)\end{array}$ & $\begin{array}{l}.004^{* * * *} \\
(.001)\end{array}$ & $\begin{array}{l}.006^{* * * *} \\
(.001)\end{array}$ & $\begin{array}{l}.006^{* * * *} \\
(.002)\end{array}$ \\
\hline$\triangle \mathrm{Ln} \_\mathrm{POS}$ & $\begin{array}{l}-.001 \\
(.001)\end{array}$ & $\begin{array}{c}-.009^{* * * *} \\
(.003)\end{array}$ & $\begin{array}{l}.011^{* * * *} \\
(.003)\end{array}$ & $\begin{array}{l}-.002 \\
(.002)\end{array}$ & $\begin{array}{l}-.003 \\
(.003)\end{array}$ \\
\hline$\Delta \mathrm{Ln} \_\mathrm{NEG}$ & $\begin{array}{l}.004^{* * * *} \\
(.001)\end{array}$ & $\begin{array}{l}.002 \\
(.002)\end{array}$ & $\begin{array}{l}.004^{* * * *} \\
(.002)\end{array}$ & $\begin{array}{l}.005^{* * *} \\
(.001)\end{array}$ & $\begin{array}{l}.004^{* * * *} \\
(.001)\end{array}$ \\
\hline$\Delta \mathrm{Ln} \_\mathrm{ITSH}$ & $\begin{array}{l}.014^{* * * *} \\
(.005)\end{array}$ & $\begin{array}{l}.055^{* * * *} \\
(.010)\end{array}$ & $\begin{array}{l}-.011 \\
(.012)\end{array}$ & $\begin{array}{l}-.009 \\
(.008)\end{array}$ & $\begin{array}{l}.042^{* * * *} \\
(.006)\end{array}$ \\
\hline$\Delta \mathrm{Ln} \_\mathrm{MSH}$ & $\begin{array}{l}.000 \\
(.006)\end{array}$ & $\begin{array}{l}.061^{* * * *} \\
(.025)\end{array}$ & $\begin{array}{l}.059^{* * * *} \\
(.021)\end{array}$ & $\begin{array}{l}-.003 \\
(.009)\end{array}$ & $\begin{array}{l}-.015 \\
(.010)\end{array}$ \\
\hline$\Delta \mathrm{Ln} \_\mathrm{SSH}$ & $\begin{array}{c}-.443^{* * *} \\
(.019)\end{array}$ & $\begin{array}{l}.138^{* * *} \\
(.066)\end{array}$ & $\begin{array}{c}-.290^{* * * *} \\
(.046)\end{array}$ & $\begin{array}{c}-.530^{* * *} \\
(.026)\end{array}$ & $\begin{array}{c}-.500^{* * * *} \\
(.040)\end{array}$ \\
\hline$\Delta \mathrm{Ln} \_\mathrm{SGov}$ & $\begin{array}{c}-.063^{* * *} \\
(.005)\end{array}$ & $\begin{array}{c}-.047^{* * * *} \\
(.011)\end{array}$ & $\begin{array}{c}-.045^{* * * *} \\
(.011)\end{array}$ & $\begin{array}{c}-.049^{* * *} \\
(.007)\end{array}$ & $\begin{array}{c}-.112^{* * * *} \\
(.012)\end{array}$ \\
\hline$\Delta \mathrm{Ln} \_\mathrm{POP}$ & $\begin{array}{l}.105^{* * * *} \\
(.031)\end{array}$ & $\begin{array}{l}.233^{* *} \\
(.112)\end{array}$ & $\begin{array}{l}.223^{* * *} \\
(.106)\end{array}$ & $\begin{array}{l}.177^{* * * *} \\
(.050)\end{array}$ & $\begin{array}{l}.144^{\text {** }} \\
(.061)\end{array}$ \\
\hline$\Delta \mathrm{Ln} \_\mathrm{HC}$ & $\begin{array}{l}-.002 \\
(.001)\end{array}$ & $\begin{array}{c}.003 \\
(.004)\end{array}$ & $\begin{array}{l}-.006^{* * *} \\
(.003)\end{array}$ & $\begin{array}{l}-.001 \\
(.002)\end{array}$ & $\begin{array}{l}.001 \\
(.003)\end{array}$ \\
\hline$\Delta \mathrm{Ln} \_\mathrm{RWAGE}$ & $\begin{array}{l}.075^{* * * *} \\
(.011)\end{array}$ & $\begin{array}{l}.184^{* * * *} \\
(.027)\end{array}$ & $\begin{array}{c}.007 \\
(.024)\end{array}$ & $\begin{array}{l}.070^{* * * *} \\
(.017)\end{array}$ & $\begin{array}{l}.054^{* * * *} \\
(.022)\end{array}$ \\
\hline Y96_99 & $\begin{array}{l}.008^{* * * *} \\
(.001)\end{array}$ & $\begin{array}{l}-.000 \\
(.002)\end{array}$ & $\begin{array}{l}.019^{* * * *} \\
(.002)\end{array}$ & $\begin{array}{l}.009^{* * *} \\
(.001)\end{array}$ & $\begin{array}{l}.003^{*} \\
(.002)\end{array}$ \\
\hline ECT & $\begin{array}{c}-.007^{* * *} \\
(.003)\end{array}$ & $\begin{array}{l}-.001 \\
(.007)\end{array}$ & $\begin{array}{c}-.042^{* * * *} \\
(.011)\end{array}$ & $\begin{array}{c}-.012^{* * *} \\
(.005)\end{array}$ & $\begin{array}{l}.021^{* * * *} \\
(.007)\end{array}$ \\
\hline $\begin{array}{l}\text { No. of Obs. } \\
\text { Wald chi2 } \\
\text { Log Likelihood }\end{array}$ & $\begin{array}{c}2431 \\
1449^{* * * *} \\
6278\end{array}$ & $\begin{array}{c}299 \\
150^{* * *} \\
858\end{array}$ & $\begin{array}{c}572 \\
454^{* * *} \\
1512\end{array}$ & $\begin{array}{c}1014 \\
920^{* * *} \\
2657\end{array}$ & $\begin{array}{c}546 \\
468^{* * *} \\
1398\end{array}$ \\
\hline
\end{tabular}

Notes: $* * *=$ Significant at $0.01 ; * *=$ Significant at $0.05 ; *=$ Significant at 0.10 


\subsection{Locating the Emergence of Key Effects in Time}

The foregoing analysis has documented a positive and significant influence of job reallocation on metroscale productivity growth across the 14-year study period beginning in 1986. Subsequent analysis has demonstrated that this finding appears to be robust across alternative spatial scales. However, what can be said about the temporal patterning of this effect? Specifically, while the effect characterizes the entire study period viewed as a temporal aggregate, has the effect been evident continuously through time? If not, when did the effect emerge in time? In order to pursue these questions, we examine the data using forward-moving recursive regression (RR) analysis which is ideally suited to locating in time the threshold when an effect acquires (or loses) statistical significance.

While conventional time series analysis focuses on the estimation of a single, temporally invariant general relationship, the RR technique can be used to recreate the historical character of "process-as-realized" dynamics (see Isaac and Griffin, 1989; Griffin and Isaac 1992; Rubin and Smith, 1992; Isaac et al., 1998). Thus, the effects of dynamic process on metro productivity growth are treated as historical contents, and the historical effects can be interpreted through the parameter structure of the coefficients such as parameter constancy, parameter drift, or parameter shifts. However, because the specific points in time used to begin and/or end a period can have profound effects on the results and conclusions in the recursive model (Isaac and Griffin 1989), the time points used in this analysis must be selected on the base of well-grounded theoretical-historical concerns of the particular investigation. In this study, 1991 is selected as an important "shift" because the U.S. economy experienced a sudden, if brief, cyclical downturn that registered fully that year.

Table 3 reports the recursive regression results. The pattern of results for the primary independent variable ( $\triangle \mathrm{Ln} \_$REAL) indicates that the employment churn effect is evident over the brief 1987-90 period and did not reemerge until 1996. There is no evidence of this effect in the 1991-95 period, after the temporary cessation of U.S. economic growth in 1990. Indeed, the rebound and resumption of growth was underway for more than four years before a job reallocation effect once again took hold. Thereafter, its effect was evident all through remaining portion of the expansion phase of the business cycle through to the end of the decade. While the time scale under examination does not permit a fuller exploration of the timing of this effect sequence, the available evidence suggests that the job reallocation influence is significantly mediated by business cycle movements, albeit with a substantial lag.

While the job reallocation influence reveals a clear emergent property tied to business cycle expansion, the influence of economic scale, as evidenced by the pattern of coefficient sign and significance on population size ( $\triangle \mathrm{Ln} \_\mathrm{POP}$ ), appears to have registered a persistent positive and significant effect all across the study period. This suggests that economic scale functions as a relatively permanent catalyst for metro-regional productivity performances, even as Schumpeterian churn effects are more cyclical.

In contrast, across this temporal landscape the independent effects of several other covariates in the model appear to be relatively enduring. The pattern of coefficients on $\Delta$ Ln_RWAGE indicates that rapid real wage growth and productivity growth are linked across the entire study period, with the sole exception of the brief recessionary period anchored to 1990-91. Moreover, the impacts of intra-sectoral industrial shifts involving both manufacturing $\left(\Delta \mathrm{Ln} \_\mathrm{MSH}\right)$ and services $\left(\Delta \mathrm{Ln} \_\mathrm{SSH}\right)$ are substantially similar across most of the study period. Indeed, both variants of private sector industrial restructuring appear to have exerted a persistent depressant effect on productivity growth throughout. While the manufacturing shift effect endured until 1997, the services shift effect characterized successive temporal increment across the entire study period. Contrastingly, by 1995 the emergence of the IT sector ( $\Delta \mathrm{Ln} \_\mathrm{IT}$ ) began to register a significant and positive impact on metro-scale productivity growth that persisted across successive specifications through to the end of the decade. A negative influence of public spending ( $\Delta$ Ln_SGov) on productivity growth is also evident continuously across the study period. Less clear-cut is the human capital ( $\triangle \mathrm{Ln} \_\mathrm{HC}$ ) (negative) effect which emerged only once to characterize the $1986-97$ period. The post-1995 IT investment surge (Y9699) effect is positive and significant across the 1996-99 period. Finally, the ECT effect is also evident annually across the entire 1986-99 period - except for when the 1990 increment was added - indicating that the adjustment to the long-term trend was a continuous one across the study period. 
International Business \& Economics Research Journal

Volume 2, Number 1

Table 3. Recursive Regression Estimates for Labor Productivity Growth Equation

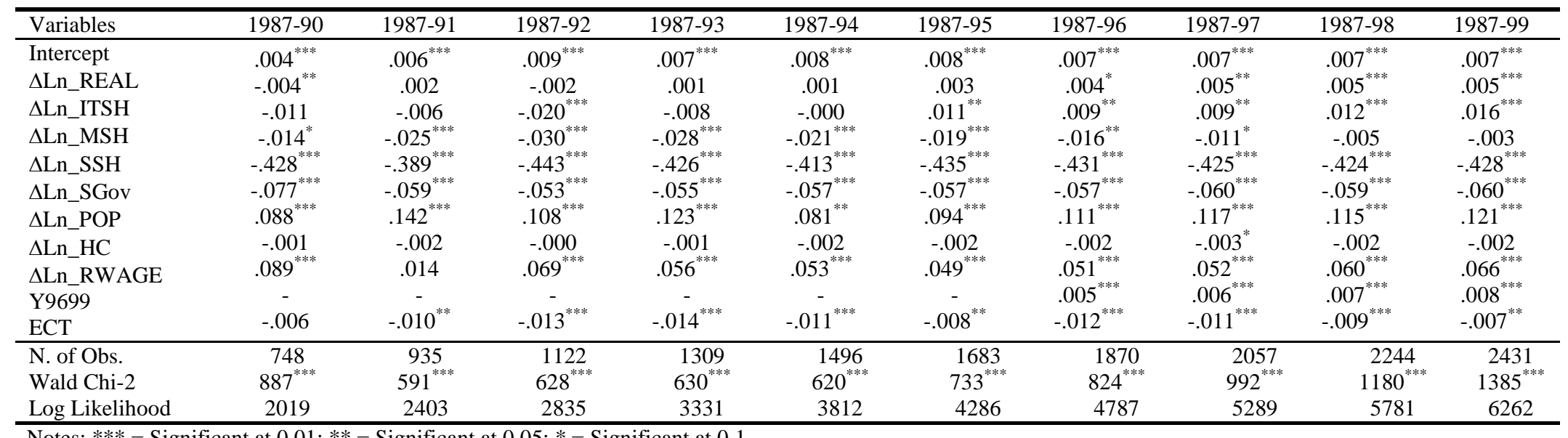

Notes: $* * *=$ Significant at $0.01 ; * *=$ Significant at $0.05 ; *=$ Significant at 0.1 
While conventional time series analysis focuses on the estimation of a single, temporally invariant general relationship, the RR technique can be used to recreate the historical character of "process-as-realized" dynamics (see Isaac and Griffin, 1989; Griffin and Isaac 1992; Rubin and Smith, 1992; Isaac et al., 1998). Thus, the effects of dynamic process on metro productivity growth are treated as historical contents, and the historical effects can be interpreted through the parameter structure of the coefficients such as parameter constancy, parameter drift, or parameter shifts. However, because the specific points in time used to begin and/or end a period can have profound effects on the results and conclusions in the recursive model (Isaac and Griffin 1989), the time points used in this analysis must be selected on the base of well-grounded theoretical-historical concerns of the particular investigation. In this study, 1991 is selected as an important "shift" because the U.S. economy experienced a sudden, if brief, cyclical downturn that registered fully that year.

Table 3 reports the recursive regression results. The pattern of results for the primary independent variable ( $\triangle$ Ln_REAL) indicates that the employment churn effect is evident over the brief 1987-90 period and did not reemerge until 1996. There is no evidence of this effect in the 1991-95 period, after the temporary cessation of U.S. economic growth in 1990. Indeed, the rebound and resumption of growth was underway for more than four years before a job reallocation effect once again took hold. Thereafter, its effect was evident all through remaining portion of the expansion phase of the business cycle through to the end of the decade. While the time scale under examination does not permit a fuller exploration of the timing of this effect sequence, the available evidence suggests that the job reallocation influence is significantly mediated by business cycle movements, albeit with a substantial lag.

While the job reallocation influence reveals a clear emergent property tied to business cycle expansion, the influence of economic scale, as evidenced by the pattern of coefficient sign and significance on population size ( $\triangle \mathrm{Ln} \_\mathrm{POP}$ ), appears to have registered a persistent positive and significant effect all across the study period. This suggests that economic scale functions as a relatively permanent catalyst for metro-regional productivity performances, even as Schumpeterian churn effects are more cyclical.

In contrast, across this temporal landscape the independent effects of several other covariates in the model appear to be relatively enduring. The pattern of coefficients on $\Delta \mathrm{Ln} \_$RWAGE indicates that rapid real wage growth and productivity growth are linked across the entire study period, with the sole exception of the brief recessionary period anchored to 1990-91. Moreover, the impacts of intra-sectoral industrial shifts involving both manufacturing $\left(\Delta \mathrm{Ln} \_\mathrm{MSH}\right)$ and services $\left(\Delta \mathrm{L}\right.$ _SSH$\left._{\text {- }}\right)$ are substantially similar across most of the study period. Indeed, both variants of private sector industrial restructuring appear to have exerted a persistent depressant effect on productivity growth throughout. While the manufacturing shift effect endured until 1997, the services shift effect characterized successive temporal increment across the entire study period. Contrastingly, by 1995 the emergence of the IT sector ( $\Delta \mathrm{Ln} \_\mathrm{IT}$ ) began to register a significant and positive impact on metro-scale productivity growth that persisted across successive specifications through to the end of the decade. A negative influence of public spending ( $\Delta$ Ln_SGov) on productivity growth is also evident continuously across the study period. Less clear-cut is the human capital ( $\left.\triangle \mathrm{Ln} \_H C\right)$ (negative) effect which emerged only once to characterize the 1986-97 period. The post-1995 IT investment surge (Y9699) effect is positive and significant across the 1996-99 period. Finally, the ECT effect is also evident annually across the entire 1986-99 period - except for when the 1990 increment was added - indicating that the adjustment to the long-term trend was a continuous one across the study period.

\section{Conclusions and Summary}

This study seeks to make a contribution to our broader understanding of the determinants of economic growth and development. The conventional literature in urban/regional economics has long emphasized the influence of scale economies and agglomeration effects in accounting for variation in economic growth across local economies. This study seeks to reach beyond the limitations of viewing urban-regional growth as an economic return to an essentially static attribute of an economy like population by probing beneath the surface to examine the component economic processes beneath the surface whose "gross" indicators are those on which net values ultimately rest. This "vertical" dimension of economic development is typically obscured from view in conventional analysis approaches (Hicks, 1991). Consequently, this study has also drawn on an embryonic literature devoted to the analysis of economic micro-level data, whereby the activities - including entry and exit - of individual firms and the employment associated with them, enrich our understanding of how economies function. 


\section{References}

1. Arrow, Kenneth J. ,H. B. Chenery, B.S. Minhas and R. M. Solow. 1961. "Capital-Labor Substitution and Economic Efficiency." Review of Economics and Statistics 43(3): 225-250.

2. Aschauer, David A. 1990. "Is Government Spending Simulative ?" Contemporary Policy Issues 8: 30-46.

3. Baily, Martin Neil, Eric J. Bartelsman, and John Haltiwanger. 1994. "Downsizing and Productivity Growth: Myth or Reality." NBER Working Paper Series No. 4741.

4. _ Charles Hulten, and David Campell. 1992. "Productivity Dynamics in Manufacturing Plants," Brookings Papers on Economic Activity: Microeconomics 1992: 187-249.

5. Baldwin, John R. 1995. "Turnover and Productivity Growth." in Baldwin (ed.), The Dynamics of Industrial Competition, Cambridge: Cambridge University Press, 208-38.

6. Barro, Robert J. 1990. "Government Spending in a Simple Model of Endogenous Growth." Journal of Political Economy 98(5): S103-S125.

7. 1991. "Economic Growth in a Cross Section of Countries." Quarterly Journal of Economics 106(2): 407-443.

8. $\quad$ Berry, Brian J. L. 1997. "Long Waves and Geography in the $21^{\text {st }}$ Century." Futures, 29(4/5): 301-310.

9. Breusch, T. and A. Pagan. 1980. "The LM Test and Its Applications to Model Specification in Econometrics." Review of Economic Studies 47 (1): 239-254.

10. Caballero, Ricardo J., and Mohamad L. Hammour. 1996. "On the Timing and Efficiency of Creative Destruction.” The Quarterly Journal of Economics 111(August): 805-851.

11. Campbell, Jeffrey R. 1998. "Entry, Exit, Embodied Technology, and Business Cycles.” Review of Economic Dynamics 1: 371-408.

12. Cooper, Russell, John Haltiwanger and Laura Power. 1997. "Machine Replacement and the Business Cycle: Lumps and Bumps.” NBER Working Paper No. 5260.

13. Davis, Steven J., John C. Haltiwanger, and Scott Schuh. 1998. Job Creation and Job Destruction. Cambridge, MA: The MIT Press.

14. $\quad$ De Gregorieo, Jose. 1992. "Economic Growth in Latin America." Journal of Development Economics 39: 59-84.

15. Denison, Edward F. 1985. Trends in American Economic Growth. Washington D.C.: The Brookings Institution. 1973. "The Shifts to Services and the Rate of Productivity Growth." Survey of Current Business 53(100): 20-35.

16. Dhrymes, Phoebus J. 1965. "Some Extensions and Tests for the CES Class of Production Function." Review of Economics and Statistics 47: 357-366.

17. Engle, Robert. F. and C. W. J. Granger. 1987. "Cointegration and Error Correction: Representation, Estimation and Testing." Econometrica 55: 251-276.

18. Florida, Richard. 1996. "Regional Creative Destruction: Production Organization, Globalization, and the Economic Transformation of the Midwest." Economic Geography 72(3): 314.

19. Glaeser, Edward L., Hedi D. Kallal, Jose A. Scheinkman and Andrei Shleifer. 1992. "Growth of Cities." Journal of Political Economy, 100(6): 1126-1152

and Jesse Shapiro. 2001. "Is There a New Urbanism? The Growth of U.S. Cities in the 1990s." Harvard Institute of Economic Research: Discussion Paper No. 1925.

20. Gordon, Robert J. 2000.'Does the 'New Economy' Measure up to the Great Inventions of the Past?" Journal of Economic Perspectives 14 (4): 49-74.

21. Greene, William H. 1997. Econometric Analysis $3^{\text {rd }}$ ed. New Jersey: Prentice-Hall, Inc.

22. Griffin, Larry J. and Larry W. Isaac. 1992. "Recursive Regression and the Historical Use of "Time" in Time-Series Analysis of Historical Process." Historical Method 25 (4): 166-179.

23. Griliches, Zvi, and Haim Regev. 1995. "Productivity and Firm Turnover in Israeli Industry: 1979-1988." Journal of Econometrics 65: 175-203.

24. Gupta, A.K. and D.L. Wilemon. 1990. "Accelerating the Development of Technology-based New Products." California Management Review 32(2): 24-44.

25. Hicks, Donald A. 2001. "Innovation Dynamics and Endogenous Adjustment in the Telecommunications Industry." Economics of Innovation and New Technology 10(2-3): 144-68.

26. __ and Steven R. Nivin. 2000. "Beyond Globalization: Localized Returns to IT Infrastructure Invest- 
ment.” Regional Studies Vol. 34(2): 115-127.

27. __ and John Rees. 1993. "Cities and Beyond: a New Look at the Nation's Urban Economy." in Sommer and Hicks (eds.), Rediscovering Urban America: Perspectives on the 1980s. U.S. Department of Housing and Urban Development: 2:1-2:125.

28. 1991. "Tracking Economic Turnover and Adjustment." Economic Development Commentary 15(2): 23-29.

29. 1987. "Geo-Industrial shifts in Advanced Metropolitan Economies," Urban Studies 24: 460-479.

30. Hoch, Irving. 1958. "Simultaneous Equation Bias in the Context of the Cobb-Douglas Production Function." Econometrica 26(4): 566-578.

31. Im, Kyung So, M. Hashem Pesaran and Yongcheol Shin. 1997. "Testing for Unit Roots in Heterogeneous Panels.” University of Cambridge: Department of Applied Economics Working Paper No. 9525.

32. Isaac, Larry W. and Larry J. Griffin. 1989. "Ahistoricism in Time-Series Analyses of Historical Process: Critique, Redirection, and Illustrations from U.S. Labor History." American Sociological Review 54: 873-890.

33. L Larry Christiansen, Jamie Miller and Tim Nickel. 1998. "Temporally Recursive Regression and Social Historical Inquiry: An Example of Cross-Movement Militancy Spillover." International Review of Social History 43: 9-32.

34. Islam, Nazrul. 1995. "Growth Empirics: A Panel Data Approach.” Quarterly Journal of Economics 110(4): 1127-1170.

35. Jorgenson, Dale and Kevin J. Stiroh. 2000. "Raising the Speed Limit: U.S. Economic Growth in the Information Age." Brookings Papers on Economic Activity 1: 125-211.

36. Knoop, Todd A. 1999. "Growth, Welfare, and The Size of Government," Economic Inquiry 37 (1): 103119.

37. Kozicki, Sharon. 1997. "The Productivity Growth Slowdown: Diverging Trends in the Manufacturing and Service Sectors," FRB of Kansas City: Economic Review First Quarter: 31-46.

38. Landau, Daniel. 1983. "Government Expenditure and Economic Growth" Southern Economic Journal 4: 783-792.

39. Lobo, Jose and Norma M. Rantisi. 1999. "Investment in Infrastructure as Determinant of Metropolitan Productivity." Growth and Change 30 (Winter): 106-127.

40. Lucas, Robert E. Jr. 1988. "On the Mechanics of Economic Development.” Journal of Monetary Economics 22: 3-42.

41. Marshall, Alfred. 1890. Principles of Economics. London: Macmillan.

42. Mills, Edwin S. 1967. "An Aggregative Model of Resource Allocation in a Metropolitan Area." The American Economic Review 57(2): 197-210.

43. Nakamura, Leonard I. 2000. "Economics and the New Economy: The Invisible Hand Meets Creative Destruction.” Federal Reserve Bank of Philadelphia: Business Review: 15-30.

44. Norton, R. D. 1986. "Industrial Policy and American Renewal." Journal of Economic Literature 24: 1-40.

45. Noyelle, T. J., and Stanback, Jr. T. M. 1983. The Economic Transformation of American Cities. New Jersey: Rowman \& Allanheld.

46. OECD. 1998. Science, Technology and Industry Outlook (Paris).

47. Olley, G. Steven and Ariel Pakes. 1996. "The Dynamics of Productivity in the Telecommunications Equipment Industry." Econometrica 64(6): 1263-1297.

48. Pineres, Shelia and Michael J. Ferrantino. 2000. Export Dynamics and Economic Growth in Latin America - A Comparative Perspective. Burlington: Ashgate.

49. Pilat, Dirk. 1998. "What Drives Productivity Growth?” The OECD Observer No. 213, August/September.

50. Ram, Rati. 1986. "Government Size and Economic Growth: A New Framework and Some Evidence from Cross-Section and Time-Series Data," American Economic Review 76 (1): 191-203.

51. Rauch, James E. 1993. "Productivity Gains from Geographical Concentration of Human Capital: Evidence from the Cities." Journal of Urban Economics 34: 380-400.

52. Richardson, Harry W. 1972. "Optimality in City Size, Systems of Cities and Urban Policy: A Sceptic's View," Urban Studies 9: 29-48.

53. Roberts, Mark J. and James R. Tybout 1996. "Industrial Evolution in Developing Countries: a Preview" in Roberts and Tybout (eds.), Industrial Evolution in Developing Countries: Micro Patterns of Turnover, 
Productivity, and Market Structure. New York: Oxford University Press for the World Bank: 1-15.

54. Romer, Paul M. 1986. "Increasing Returns and Long-run Growth." Journal of Political Economy 94: 1002-1037.

55. Rubin, Beth A. and Brian T. Smith. 1992. "Forged Ties: Cooperation and Conflict in the Metals Industries." Social Science Research 21: 115-133.

56. Schumpeter, J. A. 1934. The theory of Economic Development, Harvard University Press.

57. Sheehey, Edmund J. 1993. "The Effect of Government Size on Economic Growth," Eastern Economic Journal 19(3): 321-328.

58. Simon, Curtis J. 1998. "Human Capital and Metropolitan Economic Growth.” Journal of Urban Economics 43: 223-243.

59. Stiroh, Kevin J. 2001. "What Drives Productivity Growth?” FRBNY Economic Policy Review (March): 37-59. 